Tariq Al-Azab ${ }^{1}$, orcid.org/0000-0001-9923-4023, Jamil Haddad ${ }^{2}$, orcid.org/0000-0003-3787-0010, Fadi Alfaqs ${ }^{2}$, orcid.org/0000-0003-3427-6454
1 - Materials Engineering Department, Faculty of Engineering College, Al-Balqa Applied University, Al-Salt, Jordan 2 - Department of Mechanical Engineering, Faculty of Engineering Technology, Al-Balqa Applied University, Amman, Jordan, e-mail: $\underline{\text { drjamil@bau.edu.jo }}$

\title{
INVESTIGATION OF THE EFFECT OF SEVERAL PARAMETERS ON THE APPLICABILITY OF MAGNETIC SEPARATION METHOD
}

Purpose. This research investigates the separation process performed by a magnetic separator. The magnetic separation process is used to isolate ferrous materials from those which are not. Hence, a prototype of a dry magnetic separator is designed. It should be said that this study defines the effect of different parameters (roll speed, magnetic force, and mass of silica sand particle) on separation efficiency.

Methodology. The influence of several parameters of the magnetic separator such as magnetic force, centrifugal force, and properties of particle (mass, shape, etc.) were studied theoretically and simulated by SolidWorks software. The optimum conditions of the magnetic separator were obtained, and several trials were performed to find the point that results in a lower effect of roller speed and a higher effect of the magnetic force on the particle in order to achieve higher separating efficiency.

Findings. The results show that the centrifugal force are the most important variable influencing separating efficiency. Moreover, it was found that blade angle magnitude of (174) degree with magnetic force between $(1.71 \mathrm{E}-05$ to $6.3 \mathrm{E}-05 \mathrm{~N})$ and roll speed from (84 to $105 \mathrm{rpm}$ ) are the optimum separating conditions to reach higher rate of the separating process.

Originality. This is the first time that the effect of the gap distance between the magnet and the feeding particles on the magnetic force has been studied. Furthermore, the effect of centrifugal force on magnetic separator force is investigated theoretically and numerically in order to be compared for different parameters.

Practical value. The new prototype design of the magnetic separating unit is promising and efficient since the parameters can be varied based on the type and characteristics of materials. It is also revealed that separating time of the materials is reduced. Hence, this type of construction of a magnetic separator is recommended for industrial applications.

Keywords: magnetic separator, centrifugal force, flux density, angular velocity

Introduction. For the magnetic separation research purposes, silica sand samples were prepared from the vertical vibrating milling machine, which is available at the laboratories of the Department of Mechanical Engineering at Al-Balqa Applied University - Faculty of Engineering technology. Using the milling process, it is expected that the steel balls are being corroded hence, contaminating the silica sand with iron powder [1].

The main goal of this research work is to compare the SolidWorks software results with those which were obtained by utilizing the empirical formulas. Empirical formulas were used in direct separation of the iron contaminant caused by the corrosion action caused by friction between the steel balls and silica sand in addition to the separation of the iron content in the silica sand [1]. The mixture obtained was placed in a magnetic separator machine for purification process in order to use it in various aspects.

The differences in magnetic susceptibility of minerals is one of the most important factors utilized in magnetic separation process which aims at mineral concentration. It should be mentioned that Mineral particles are usually classified into three different categories; paramagnetic, ferromagnetic, and diamagnetic.

Ferromagnetic minerals are widely treated in a highly efficienct magnetic separator where separation of minerals based on magnetic susceptibility can be performed as wet or dry and by different machine configurations. It should be mentioned that selecting the machine/technology depends on multiple factors including particle size, assembly of minerals, and magnetic susceptibility [2].

Theoretical study of magnetic separation mechanism of particles is well discussed in literature [3], where application of dry high-intensity magnetic separation was frequently used lately which produced new concepts of application approaches and design concepts in the separators considered. However, there are different separators which have been designed to facilitate separating minerals to be treated based on the required magnetic field along with other criterias. Magnetic separators are classified into

(C) Tariq Al-Azab, Jamil Haddad, Fadi Alfaqs, 2021 two groups; first dry and wet processing. In this research the dry magnetic separation method was completely used [4].

Depending on the previous studies on different types of magnetic separators, it is found that the best type corresponding with the current work is the dry drum low-intensity magnetic separator with magnetic induction $(0.3-1.2 \mathrm{~T})$ due to its low capital, operating cost and maintenance cost, simple design, and good separation efficiency. However, in order to enhance the separation efficiency of this type of magnetic separators, a drum dry High-intensity magnetic separator with magnetic induction $(1.5-3 \mathrm{~T})$ is used.

Fig.1 shows the main components of the magnetic separator, which is designed and manufactured at Al-Balqa Applied University. The different thing in this device is feeding rate where the particles going from plate or blade 8 to the roll 1 by the vibration forces 6 that act on the blade 8 installed on four springs to be separated. When the motor's 5 shaft starts rotating the rotating masses start rotating with motor speed that will give us an amplitude to make the particle moving down by vibration forces.

A simple and basic approach to eliminate tramp iron from material on a transport line is through an attractive head pulley, these are accessible both in perpetual magnet and electromagnetic development, they are moderately reasonable, simple to introduce, and achieve nonstop vagrant iron evacuation

Material carried on the transport disregards the attractive pulley which holds the attractive particles until they leave the district of the attractive field while the non-attractive material is released over the pulley.

Theoretical studies on Magnetic Separator. Literature review. Mineralogical analyses conducted, showed that hematite and goethite are considered as the major iron minerals in the ore. Moreover, simulation results revealed that Fe recovery of about $80 \%$ and a concentration up to $60.45 \%$ of Fe grade can be obtained for a cyclone plant with $3.1 \mathrm{~g} / \mathrm{cm}^{3}$ separation density and $-9.5+0.5 \mathrm{~mm}$ feed size [5].

The authors (S. Bouabdallah, et al.) and Y. C. Tosun, et al., studied the main parameters affecting leaching process in var- 


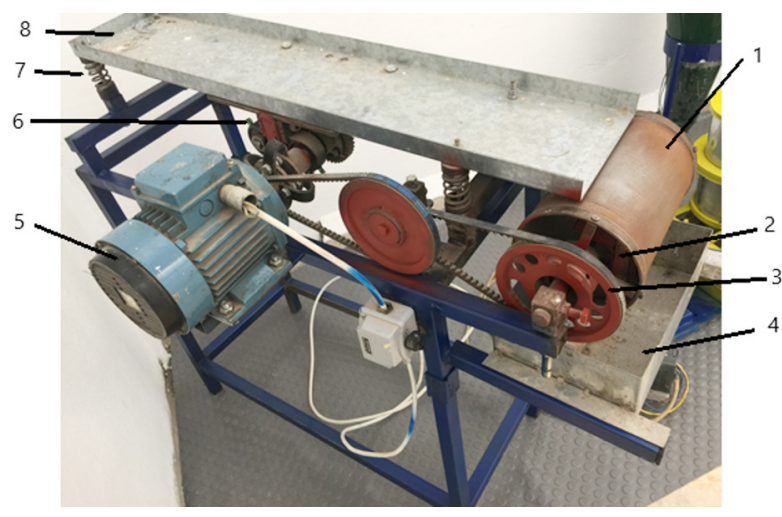

Fig. 1. Laboratory model of the magnetic separator:

1 - roll; 2 - magnets; 3 - pulley; 4 - splitter tank; 5 - electrical motor; 6 - rotating mass; 7 - springs; 8 - blade

ious ranges of crushed and sieved sandstone. Therefore, the dry high intensity magnetic separator was utilized for sandstone separation. This study shows that the employment of hydrochloric acid as the leaching allows reducing the iron content percentage in quartz sand significantly, while on the other hand, wet sieving process is found to remove only the fraction of these contaminating minerals $(<125 \mu \mathrm{m})$. Furthermore, it was recommended that magnetic separation implementation required further study and proof [6].

Qin Xing Zong studied the effect of magnetic separation process on dry earth roll magnetic separator where results obtained indicated that both roll speed and magnetic separator position had much more significant influence than the feed rate. Moreover, results clearly showed that increasing the roll speed lead to magnetic product grade increase. However, it is found also that intermediate level of roll speed produced higher value of the separation efficiency [7]. It should be said that when increasing the feed rate, the product increase gradually, but as the feed rate increased further the separation process was found to be ineffective where the grade and recovery rate were reduced. Another study by W. Dahani based on the separation of the chromite sand grade concluded that for faster feeder speed, Cr grade produced was finer where the best feeder speed was found $60(\mathrm{~kg} / \mathrm{hr})$ [8]. Furthermore, results showed that splitter position played a significant role when obtaining the grade and recovery rate of feed samples where it was observed that large amount of magnetic and non-magnetic material is sorted when lower splitter position was used [7]. Another study conducted by Mert Terzi based on the magnetic separation fractions from $\mathrm{Na}$-feldspar ore showed that separator angle (splitter position) plays a significant role influencing separation recovery [9]. In case of using dry high intensity magnetic separator, the best splitter inclination was found as $74.9^{\circ}[10]$.

Effect of both magnetic roll speed and separator position on particle separation process for different sizes was investigated where it has been concluded that the smaller particle size range produced enhanced efficiency when compared to a wider range of particle sizes [7]. Another study conducted by Mehmet Tanriverdi is based on the separation of specular hematite. It was found that better performance was achieved when the dry high magnetic separator was fed by fine particle size fraction $(-106 \mu \mathrm{m})$ [11]. However, magnetic separation of iron ore was investigated by A. M. Ezhov, Y. B. Shvaljov. The results revealed that using low intensity dry magnetic separation on particle size of $15 \mu \mathrm{m}$ leads to maximum efficiency [12].

Reduction of ash and Sulfur contents using high intensity dry magnetic separation was studied by K. T. Perek where it was found that the magnetic separation efficiency of removing sulfur increased with decreasing particle size [13].

Bayat O., and et al., studied the effect of magnetic strength by using the dry magnetic separator. It was observed that the available range of magnetic strength is $3800-8200$ Gauss [14].
The effect of blade angle on separation process was investigated by Mert Terzi where it was concluded that the best degree of blade angle is $130^{\circ}$ [9].

In case of using the belt in dry high intensity magnetic separator, the best belt speed is found as 73 RPM, and in case of using a shaking table device the best result is $4.13^{\circ}$ of inclination angle, $2.5 \mathrm{~cm}$ stroke length and feed rate $307.6 \mathrm{Gm} / \mathrm{min}$ [10]. Furthermore, in case of using drum dry magnetic separation instead of roll dry magnetic separation, the best speed of the drum is measured as 154 RPM [12]. While using two stage perm roll separation the recovery of chlorite in the non-magnetic tailings was probably about 20 to $30 \%$ [15].

Previous theoretical studies mentioned above investigated the effect of several parameters on magnetic separation, but did not study the effect of the gap distance between the magnet and the feeding particles on the magnetic force or the effect of centrifugal force on magnetic force. Therefore, these two parameters are studied in this research in order to observe their effect on the magnetic flux density and magnetic force.

Simulation and results. The results showed that Magnetic Flux density decreases as the gap distance increases where every magnet contains a constant magnetic flux density. The magnetic field lines density decreases when the distance is increased. That means the magnetic force decreased with decreasing the magnetic flux density. The attractive power is inversely proportional to the distance squared $\left(F \propto 1 / r^{2}\right)$, where $r$ is the distance between the magnets.

In order to find out magnetic force that will affect the particles, position of these particles should be selected since the force will vary according to their position.

Fig. 2 illustrates the steel particles' position where a particle is placed every 30 degree. It should be observed that two sizes of particle diameters ( 1 and $0.7 \mathrm{~mm}$ ) are used.

In each experiment, 12 particles are located at the roll surface (one particle every 30 degree). The magnetic flux density and rotational speed which affect the separating process efficiency varied $0-3$ Tesla and (600-1100 RPM) respectively.

The magnetic flux density is found to be maximum at the roll surface as shown in Fig. 3. This is reasonable since the distance considered in this part is very close to the magnets, and gradually decreases towards the magnetic pole. All of the magnetic flux density values were simulated by SolidWorks software and calculated theoretically by empirical formulas.

Effect of magnetic flux density. The intensity of permanent magnet is related to the magnet material and pole gap. As the magnetic flux is inversely proportional to the square of the air gap, the higher value of magnetic field is obtained for a smaller air gap [16]

$$
f_{m}=X m H \nabla B,
$$

where $m$ is mass of particle; $X$ is mass magnetic susceptibility; $H$ is magnetic flux density; $B$ is magnetic field gradient.

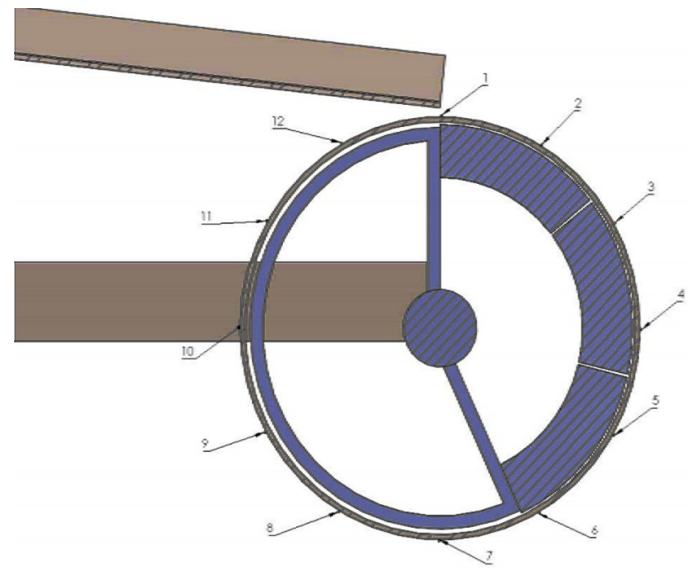

Fig. 2. Particles position 


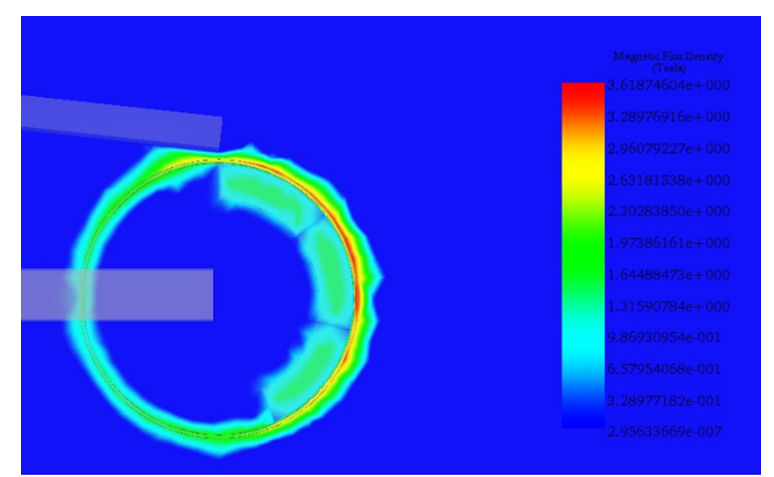

Fig. 3. Magnetic Flux density without particles

Effect of roll speed. The rotor speed is one of the most important variables affecting magnetic separator efficiency since it controls centrifugal force that acts on the particle. Centrifugal force is directly proportional with the rotor's radius and square of angular velocity as shown in equation. Hence, should the rotor speed increases, the centrifugal force will increase as a result [16]

$$
f_{c}=m \omega^{2} R,
$$

where $m$ is mass of the particle; $\omega$ is angular velocity of the rotor; $R$ is radius of the rotor.

Effect of feed rate. Feed rate is a parameter concerned with the thickness of layer at the roll surface. It should be said that a thicker layer produces less separation process efficiency since a higher number of particles will not be subjected to magnetic field.

Effect of particle size. The particle size affects directly the gravitational force as shown in equation since the particle mass is proportional to its size, to the magnetic flux density and the gravitational force, when the size increased, the mass will be increased, which means the gravitational force will be increased [16]

$$
f_{g}=m g
$$

where $m$ is mass of particle; $g$ is gravity acceleration.

Fig. 4 shows magnetic flux density for $1 \mathrm{~mm}$ particle diameter with the number of particles $=12$.

It should be said that SolidWorks software shows force density at each particle considered.

Fig. 5 illustrates the effect of magnetic flux density at particles due to their position on the roll surface for 4 positions: 1 , 3, 6 and 9. Know that this analysis was done on a material size of 1 and $0.7 \mathrm{~mm}$

Comparison between SolidWorks output and theoretical results is presented in Table 1 and Fig. 6 for particle diameter $1 \mathrm{~mm}$, where good agreement was found.

Fig. 7 presents the relation between, centrifugal force induced in the magnet separator and the magnetic force where it

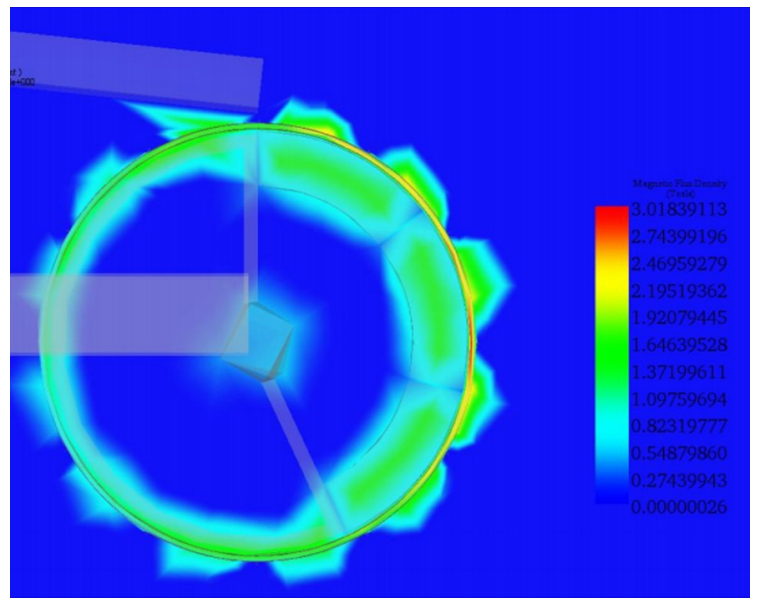

Fig. 4. Magnetic Flux density with 1mm particle diameter is clearly seen that increasing centrifugal force, the effect of magnetic force decreases. As a result, optimum values should be taken at the lowest values of centrifugal force and highest values of magnetic force. However, increasing roll velocity leads to centrifugal force rise since the angular velocity increases as well.

Fig. 8 shows the effect of magnetic flux density on particles with respect to their position on the roll surface for particle diameter $0.7 \mathrm{~mm}$. However, the numerical values obtained in SolidWorks software and theoretical values were compared in Table 2 and Fig. 9, where good agreement was observed.

The effect of particle size on centrifugal force was investigated for magnetic force variation (5E-12 to $8 \mathrm{E}-5 \mathrm{~N}$ ) as seen in Fig. 10. It should be observed that should the particle diameter increase, centrifugal force needed for separation increases for magnetic
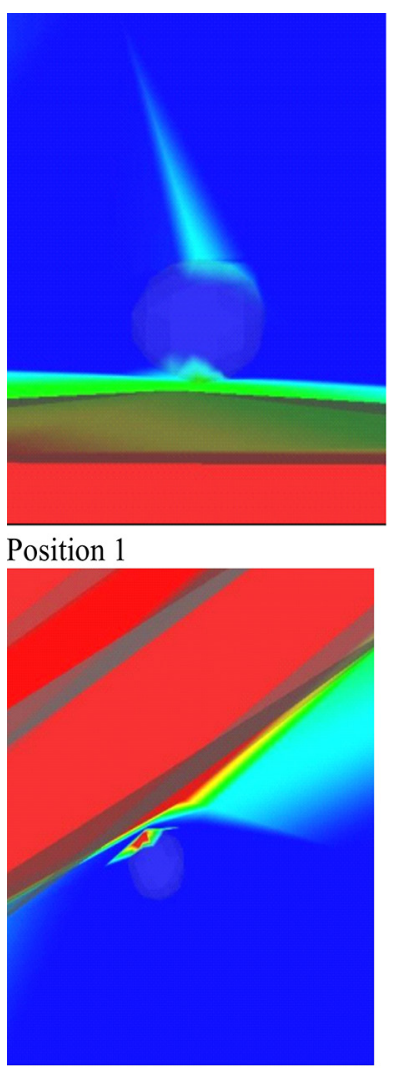

Position 6

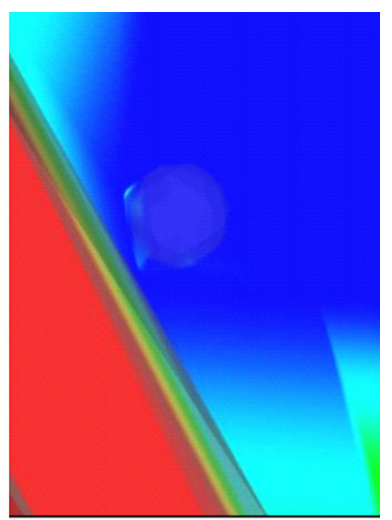

Position 3

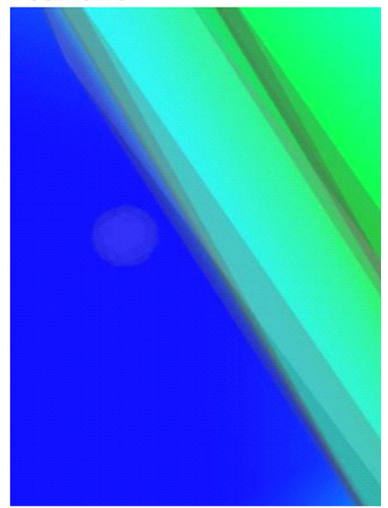

Position 9

Fig. 5. Force density at position 1, 3, 6 and 9

Table 1

Simulation and theoretical values for $1 \mathrm{~mm}$ diameter

\begin{tabular}{|c|c|c|c|c|}
\hline \multicolumn{2}{|c|}{ SoildWorks Values } & \multicolumn{2}{|c|}{ Theoretically values } & Accuracy \\
\hline $\begin{array}{c}\text { Force } \\
\text { density } \\
\left(\mathrm{N} / \mathrm{m}^{3}\right)\end{array}$ & $\begin{array}{c}\text { Force } \\
(\mathrm{N})\end{array}$ & $\begin{array}{c}\text { Force } \\
(\mathrm{N})\end{array}$ & $\begin{array}{c}\text { Force } \\
\text { density } \\
\left(\mathrm{N} / \mathrm{m}^{3}\right)\end{array}$ & $\begin{array}{c}\text { Accu. } \\
\%\end{array}$ \\
\hline 100000 & $5.24 \mathrm{E}-05$ & $6.86 \mathrm{E}-05$ & $1.31 \mathrm{E}+05$ & 68.90 \\
\hline 90900 & $4.76 \mathrm{E}-05$ & $6.24 \mathrm{E}-05$ & $1.19 \mathrm{E}+05$ & 68.88 \\
\hline 81800 & $4.28 \mathrm{E}-05$ & $5.62 \mathrm{E}-05$ & $1.07 \mathrm{E}+05$ & 68.87 \\
\hline 72700 & $3.81 \mathrm{E}-05$ & $4.99 \mathrm{E}-05$ & $9.53 \mathrm{E}+04$ & 68.85 \\
\hline 63600 & $3.33 \mathrm{E}-05$ & $4.37 \mathrm{E}-05$ & $8.34 \mathrm{E}+04$ & 68.82 \\
\hline 54500 & $2.85 \mathrm{E}-05$ & $3.74 \mathrm{E}-05$ & $7.15 \mathrm{E}+04$ & 68.79 \\
\hline 45500 & $2.38 \mathrm{E}-05$ & $3.12 \mathrm{E}-05$ & $5.96 \mathrm{E}+04$ & 69.03 \\
\hline 36400 & $1.91 \mathrm{E}-05$ & $2.49 \mathrm{E}-05$ & $4.77 \mathrm{E}+04$ & 69.21 \\
\hline 27300 & $1.43 \mathrm{E}-05$ & $1.87 \mathrm{E}-05$ & $3.58 \mathrm{E}+04$ & 69.21 \\
\hline 18200 & $9.53 \mathrm{E}-06$ & $1.25 \mathrm{E}-05$ & $2.38 \mathrm{E}+04$ & 69.21 \\
\hline 9090 & $4.76 \mathrm{E}-06$ & $6.24 \mathrm{E}-06$ & $1.19 \mathrm{E}+04$ & 68.88 \\
\hline
\end{tabular}




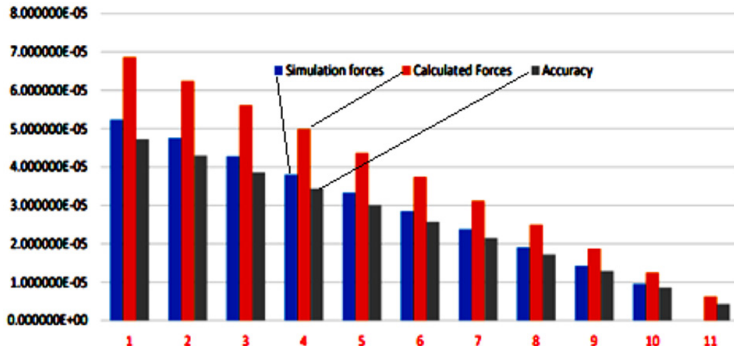

Fig. 6. Comparison between theoretical and simulated forces

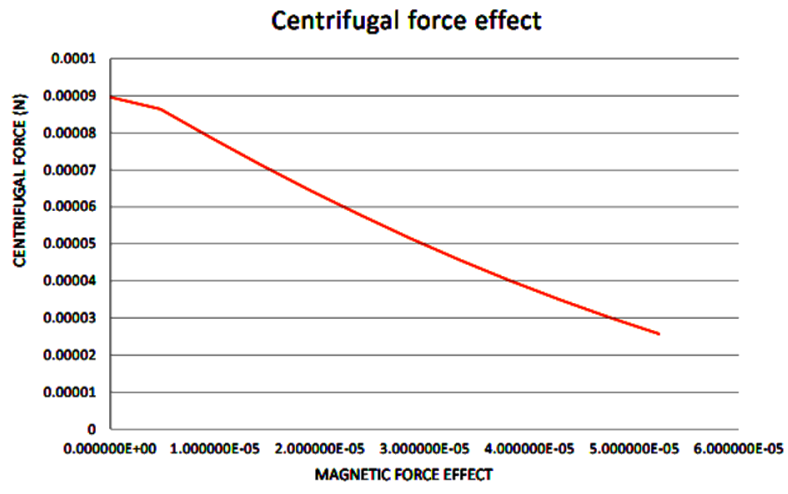

Fig. 7. Relation between the centrifugal force and magnetic force effect $1 \mathrm{~mm}$ particle diameter

force variation considered. However, for each particle size considered, centrifugal force drops when magnetic force increases.

Similarly, it can be clearly seen that increasing roll speed leads to centrifugal force increase for both particle sizes considered as depicted in Fig. 11. On the other hand, increasing the particle diameter leads to centrifugal force drop for roll speed variation considered. Hence, it is concluded that particle size plays a vital role in magnetic separation process since it is directly proportional to particle mass.

It should be mentioned that the best experimental results are obtained at minimum values of centrifugal force and maximum values of magnetic force at the same instance. The positive values of resultant force mean that the magnetic force is larger than centrifugal force, thus the particles are separated whereas negative values indicate that the magnetic force is lower than the centrifugal force, thus, the particles are not be attracted. Therefore, increasing resultant force leads to increase in the separation efficiency.

Conclusions. For particles with $1 \mathrm{~mm}$ diameter, the mass of particle is $4.121 \mathrm{E}-06 \mathrm{~kg}$. Optimum experimental result occurs at

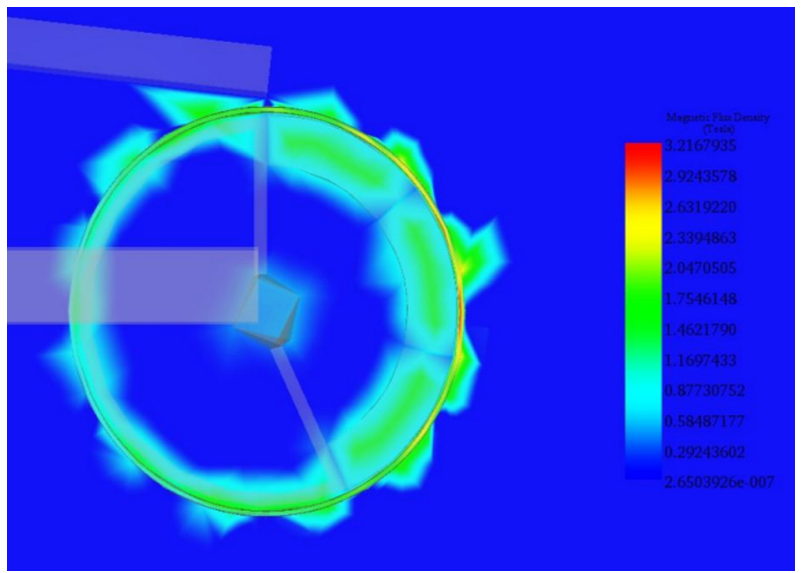

Fig. 8. Magnetic Flux density with $0.7 \mathrm{~mm}$ particle diameter
Simulation and theoretical values for $0.7 \mathrm{~mm}$ diameter

\begin{tabular}{|c|c|c|c|c|}
\hline \multicolumn{2}{|c|}{ SoildWorks Values } & \multicolumn{2}{c|}{ Theoretically values } & Accuracy \\
\hline $\begin{array}{c}\text { Force } \\
\text { density } \\
\left(\mathrm{N} / \mathrm{m}^{3}\right)\end{array}$ & $\begin{array}{c}\text { Force } \\
(N)\end{array}$ & $\begin{array}{c}\text { Force } \\
(\mathrm{N})\end{array}$ & $\begin{array}{c}\text { Force } \\
\text { density } \\
\left(\mathrm{N} / \mathrm{m}^{3}\right)\end{array}$ & $\begin{array}{c}\text { Accu. } \\
\%\end{array}$ \\
\hline 100000 & $1.80 \mathrm{E}-05$ & $2.35 \mathrm{E}-05$ & $1.40 \mathrm{E}+05$ & 69.44 \\
\hline 90900 & $1.63 \mathrm{E}-05$ & $2.14 \mathrm{E}-05$ & $1.27 \mathrm{E}+05$ & 68.71 \\
\hline 81800 & $1.47 \mathrm{E}-05$ & $1.93 \mathrm{E}-05$ & $1.14 \mathrm{E}+05$ & 68.71 \\
\hline 72700 & $1.30 \mathrm{E}-05$ & $1.71 \mathrm{E}-05$ & $1.01 \mathrm{E}+05$ & 68.46 \\
\hline 63600 & $1.14 \mathrm{E}-05$ & $1.50 \mathrm{E}-05$ & $8.90 \mathrm{E}+04$ & 68.42 \\
\hline 54500 & $9.78 \mathrm{E}-06$ & $1.28 \mathrm{E}-05$ & $7.63 \mathrm{E}+04$ & 69.12 \\
\hline 45500 & $8.17 \mathrm{E}-06$ & $1.07 \mathrm{E}-05$ & $6.36 \mathrm{E}+04$ & 69.03 \\
\hline 36400 & $6.53 \mathrm{E}-06$ & $8.56 \mathrm{E}-06$ & $5.08 \mathrm{E}+04$ & 68.91 \\
\hline 27300 & $4.90 \mathrm{E}-06$ & $6.42 \mathrm{E}-06$ & $3.57 \mathrm{E}+04$ & 68.98 \\
\hline 18200 & $3.27 \mathrm{E}-06$ & $4.28 \mathrm{E}-06$ & $2.54 \mathrm{E}+04$ & 69.11 \\
\hline 9090 & $1.63 \mathrm{E}-06$ & $2.14 \mathrm{E}-06$ & $1.27 \mathrm{E}+04$ & 68.71 \\
\hline
\end{tabular}

For $0.7 \mathrm{~mm}$ Particle Diameter

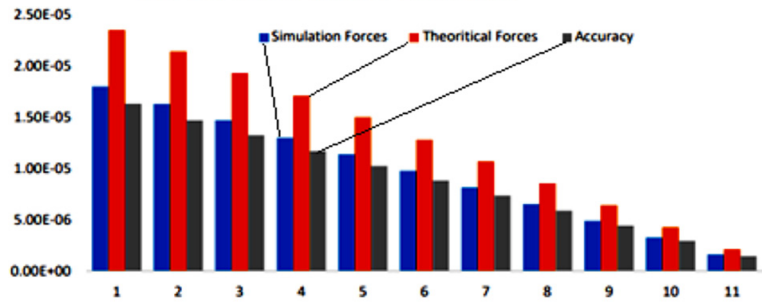

Fig. 9. Comparison between theoretical and simulated forces

Effect of centrifugal force on different sizes of particles

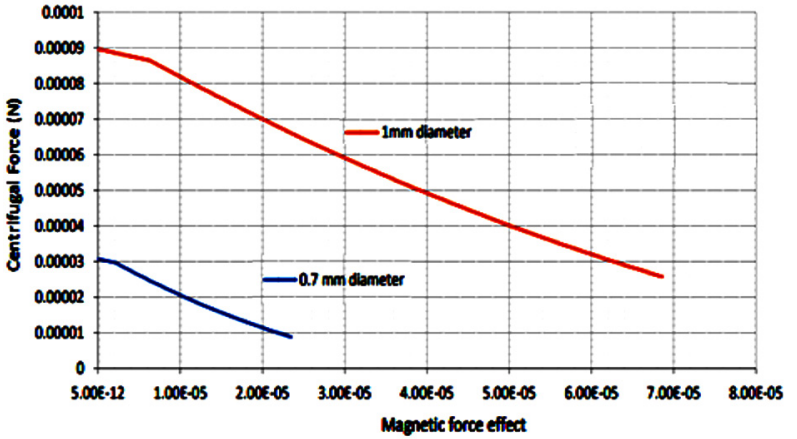

Fig. 10. Relation between the centrifugal force and magnetic force effect for different diameters of particles

Roll Speed Versus Centrifugal Force

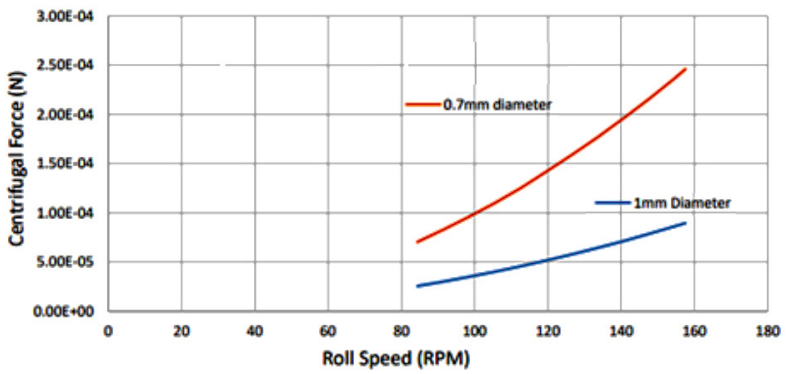

Fig. 11. Relation between the centrifugal force and roll speed for different diameters of particles 
$84.38 \mathrm{rpm}$ of roll speed since the lowest value of centrifugal force $2.57 \mathrm{E}-05 \mathrm{~N}$ and highest value of resultant force 4.29E- $05 \mathrm{~N}$ are recorded. As a result, the particle is separated. For $0.7 \mathrm{~mm}$ diameter, the mass of particle is calculated as $1.41 \mathrm{E}-06 \mathrm{~kg}$ which is less than $1 \mathrm{~mm}$ particle's mass. Best reading is observed at $84.38 \mathrm{rpm}$ of roll speed. This speed induces a centrifugal force $8.82 \mathrm{E}-06 \mathrm{~N}$, which is lower than magnetic force $2.35 \mathrm{E}-05 \mathrm{~N}$. The device considered produces reliable at various roll speeds (of 84.38, 91.41, 98.44, 105.47 RPM), but the highest efficiency is observed at 84.38 RPM. However, operating at roll speeds $(112.5,119.53,126.56,133.59,140.63,147.66,154.69 \mathrm{RPM})$ is not recommended since the centrifugal force is higher than the magnetic force where particles will not be separated.

Several parameters have been considered and measured in this experiment such as roll speed and magnetic force. For most cases ( 84 to 105 RPM) as roll speed increases, the particle needs more magnetic force to overcome the centrifugal force which increases as roll speed increases. As presented in the results for particle diameter of 0.70 and $1 \mathrm{~mm}$, should the roll speed should increase. However, it is found that the efficiency of dry high magnetic separator intensity depends on roll speed, particle size, magnetic flux on the particle, magnetic susceptibility for the particle, and magnetic field gradient. In the theoretical analysis, it was found that the roll speed, magnetic force, and particle mass are the most important parameters influencing the magnetic separation efficiency. The positive sign of resultant force value indicates to successful particle separation process since the magnetic force is greater than centrifugal force.

This work has been carried out during sabbatical leave granted to the author Tariq Al-Azab from Al-Balqa Applied University during the academic year 2020/2021.

\section{References.}

1. Haddad, J. (2020). Experimental Study of the Effect of Ball Diameter, Rotating Mass and Input Grain Size of Silica Sand on the Efficiency of Milling in Vertical Vibrating Mil. International Journal of Mechanical and Production Engineering Research and Development (IJMPERD), 10(1), 355-368. https://doi.org/10.24247/ijmperdfeb202030.

2. Joan S. Esterle (2008). Chapter 3 - Mining and Beneficiation. In Isabel Suárez-Ruiz, \& John C. (Eds.). Crelling, Applied Coal Petrology, (pp. 61-83). Elsevier. https://doi.org/10.1016/B978-0-08-045051-3.00003-8. 3. Prokopiev, S. A., Pelevin, A. E., Prokopiev, E. S., \& Ivanova, K. K. (2019). Increasing the Integrity of Iron-Ore Raw Material Use with the Help of Screw Separation. Izvestiya Vysshikh Uchebnykh Zavedenii. Gornyi Zhurnal News of the Higher Institutions. Mining Journal, (6), 7080. https://doi.org/10.21440/0536-1028-2019-6-70-80.

4. Sunil Kumar Tripathy, P. K. Banerjee, Nikkam Suresh, Y. Rama Murthy, \& Veerendra Singh (2017). Dry High-Intensity Magnetic Separation In Mineral Industry. A Review Of Present Status And Future Prospects, Mineral Processing and Extractive Metallurgy Review, 38(6), 339-365. https://doi.org/10.1080/08827508.2017.1323743.

5. A. Aghlmandi Harzanagh, \& Ergün, S.L. (2015). Beneficiation of Dry Magnetic Separator tailings using dense medium cyclones: A simulation study, $24^{\text {th }}$ International Mining Congress and Exhibition of Turkey. April 14-17. Retrieved from https://www.maden.org.tr/resimler/ekler/bb17a0e751d1d74_ek.pdf.

6. Tosun, Y. C., Tuncuk, A., Okudan, M. D., \& Akcil, A. (2020). Removal of Iron from Quartz Ore by Physical Enrichment and Hydrometallurgical Methods. DEUFMD 22(64), 187-197. https://doi. org/10.21205/deufmd.2020226419.

7. Qin Xing Zong, Luo Zhen Fu, \& Lv Bo (2019). Variables and Applications on Dry Magnetic Separator. E3S Web Conference, 53. https://doi.org/10.1051/e3sconf/20185302019.

8. Subandrio, S., Dahani, W., Alghifar, M., \& Purwiyono, T. (2019). IOP Conference Series: Materials Science and Engineering, Eng. 588 012033. https://doi.org/10.1088/1757-899x/588/1/012033. 9. Kursun, I., Terzi, M., \& Ozdemir, O. (2018). Evaluation of digital image processing (DIP) in analysis of magnetic separation fractions from Na-feldspar ore. Arabian Journal of Geosciences, 11, 462. https:// doi.org/10.1007/s12517-018-3833-7.

10. Youssef, M.A., Abd El-Rahman, M.K., Helal, N.H., El-Rabiei, M. M., \& Elsaidy, S. R. (2009). Optimization of Shaking Table and Dry Magnetic Separation on Recovery of Egyptian Placer Cassiterite Using Experimental Design Technique. The Journal of ORE DRESSING, 11(22), 1-9.
11. Tanriverdi Mehmet, Sezai Sen, \& Tayfun Ciçek (2018). Micaceous iron oxide production by application of magnetic separation. Physicochemical Problems of Mineral Processing, 54(2), 546-553. https://doi. org/10.5277/ppmp1845.

12. Ezhov, A. M., \& Shvaljov, Y. B. (2015). Dry Magnetic Separation of Iron Ore of the Bakchar Deposit. Procedia Chemistry, 15, 160-166. https://doi.org/10.1016/j.proche.2015.10.026.

13. Atesok, G., Perek, K. T., Dincer, H., \& Celik, M.S. (1999). Reduction of Ash and Sulfur Contents of Low-RankTurkish Semicoked Lignite by High Intensity Dry Magnetic Separation. Coal Preparation, 20(3-4), 179-190. https://doi.org/10.1080/07349349908945599.

14. O. Bayat, and et al. (2006). Upgrading of Chromite Concentrate by High Intensity Dry Magnetic Separation, XXIII. International Mineral Processing Congress, IMPC, 3-8 September, Istanbul, Turkey. Retrieved from http://www.impc2006.org.

15. Kleiv, R. A., \& Thornhill, M. (2011). Dry magnetic separation of olivine sand. Physicochemical Problems of Mineral Processing, 47, 213-228. 16. Svoboda, J. (2004). Magnetic Techniques for the Treatment of Materials. Boston, Kluwer Academic Publ. 99. https://doi.org/10.1007/14020-2107-0.

\section{Дослідження впливу кількох параметрів на використання методу магнітної сепарації}

\section{Тарик Аль-Азаб ${ }^{1}$, Джаміль Хаддад ${ }^{2}$, Фаді Альфакс ${ }^{2}$}

1 - Кафедра матеріалів, факультет інженерного коледжу, Аль-Балка прикладний університет, м. Ал-Салт, Йорданія 2 - Кафедра машинобудування, факультет інженерних технологій, Аль-Балка прикладний університет, м. Амман, Йорданія, e-mail: drjamil@bau.edu.jo

Мета. Ця робота досліджує процес поділу, що виконується магнітним сепаратором. Процес магнітної сепарації використовується для відділення чорних металів від інших. Таким чином, розроблений прототип сухого магнітного сепаратора. Слід сказати, що це дослідження визначає вплив різних параметрів (швидкості обертання валка, магнітної сили і маси частинок кварцового піску) на ефективність розділення.

Методика. Вплив декількох параметрів магнітного сепаратора, таких як магнітна сила, відцентрова сила та властивості частинок (маса, форма і т. д.), було теоретично вивчено та змодельовано за допомогою програмного забезпечення SolidWorks. Були отримані оптимальні умови магнітного сепаратора, і було проведено кілька випробувань, щоб знайти точку, яка призводить до меншого впливу швидкості ролика й більшого впливу магнітної сили на частку для досягнення більш високої ефективності поділу.

Результати. Результати показують, що відцентрова сила є найбільш важливою змінною, яка впливає на ефективність розділення. Більш того, було виявлено, що величина кута диска (174) градусів з магнітною силою від (1,71E-05 до 6,3Е-05 Н) і швидкістю валка від (84 до 105 об/хв) є оптимальними умовами поділу для досягнення більш високої швидкості процесу поділу.

Наукова новизна. Це перший раз, коли вивчається вплив зазору між магнітом і частинками, що подаються, на магнітну силу. Крім того, вплив відцентрової сили на силу магнітного сепаратора досліджено теоретично й чисельно з метою порівняння для різних параметрів.

Практична значимість. Новий прототип установки магнітної сепарації перспективний і ефективний, так як параметри можуть варіюватися в залежності від типу та характеристик матеріалів. Також виявлено, що час поділу матеріалів скорочується. Отже, така конструкція магнітного сепаратора рекомендується для промислового застосування.

Ключові слова: магнітний сепаратор, відиентрова сила, щільність потоку, кутова швидкість

Recommended for publication by Professor Faisal Al-Ghathian. The manuscript was submitted 17.02.21. 